\title{
BIOCHEMICAL AND HISTOLOGICAL INDICATORS OF BLOOD AND M. LONGISSIMUS DORSI OF YOUNG BULLS OF KAZAKH WHITE-HEADED BREED OF DIFFERENT GENOTYPES BY THE CAPN1 AND GH GENES
}

\author{
Marina I. Selionova*, Viktoria R. Plakhtyukova \\ Russian State Agrarian University - Moscow Timiryazev Agricultural Academy, Moscow, Russia
}

Keywords: kazakh white-headed breed, gene of growth hormone, calpain gene, histological, chemical analysis of muscle tissue, fatty acid composition of blood

\begin{abstract}
The use of molecular genetic markers for productivity is one of the modern approaches in breeding beef cattle. The article presents the results of the studies on the influence of genotypes by the calpain (CAPN1) and growth hormone (GH) genes on live weight, fatty acid composition of blood plasma, quantitative and qualitative indicators of meat of young cattle of Kazakh white-headed breed. It was established that animals of the homozygous geno-types CC-CAPN1 and VV-GH had a larger live weight and its average daily gain on the $240^{\text {th }}$ and $365^{\text {th }}$ days. Their superiority over the $G G$ and LL genotypes was $13.8 \%(P<0.05)$ and $6.9 \% ; 14.6 \%(P<0.05)$ and $6.9 \%$, respectively. The carriers of the desirable alleles in the homozygous state had the sum of unsaturated fatty acids higher by $6.3 \%$ and $7.1 \%$, respectively, than the young bulls, in which genotypes they were absent. The predominance of unsaturated fatty acids over saturated fatty acids also determined lower values of lipid me-tabolism direction index (0.92 and 1.00) in the animals with the desirable genotype. Muscle tissue of animals of the CC and VV genotypes was characterized by a higher level of protein, fat by 0.28-2.13 abs. per cent, energy value, and the quantity of muscle fibers with a smaller diameter per unit area compared to the GG and LL genotypes by on average $8.7 \%$ and $25.5 \%(P<0.01)$. Due to the greater number of interfiber fat inclusions, muscle tissue of the desirable genotypes received higher marbling scores. The obtained data testify to the prospects of replication of animals, which genotype has the desirable alleles for further improvement of traits of meat productivity of Kazakh white-headed breed.
\end{abstract}

Funding: The study was financed by the grant of the Russian Foundation for Basic Research (Project No.19-316-90061/19).

\section{Introduction}

One of the main tasks in selective breeding is selection and breeding of animals with targeted economic traits. This result can be achieved by using genetic markers for productive traits. The use of genetic markers in beef cattle selection in combination with the main zootechnic methods for animal breeding make it possible to significantly accelerate the process of creation of herds with genetically preset potential of high productivity $[1,2,3]$.

The calpain gene (CAPN1) can be considered one of the candidate genes that are directly associated with meat tenderness and marbling. The mechanism of its action consists in the fact that the calpain system creates conditions for uniform distribution of intramuscular fat between fibers on the basis of calcium-dependent cysteine protease due to decomposition of the so-called Z-discs of skeletal muscles and weakening of bonds between muscle fibers, which ensures the so-called marbling and corresponding meat tenderness and juiciness $[4,5]$.

The biological effect of the growth hormone gene (GH) consists in regula-tion and stimulation of many metabolic processes. The hormone (somatotropin) controlled by GH is produced by the anterior lobe of the hypophysis and plays a key role in carbohydrate and lipid metabolism $[6,7,8]$.

It is known that lipids are very active in terms of metabolism; they act not only as a source of energy but also have more significant functions - structural and regulatory. Lipids take part in the metabolic processes mainly as free saturated and unsaturated fatty acids. It is also necessary to note that fatty acids not only play a key role in the vital activities of the body and formation of productivity, but several of them act as signal molecules involved in the process of expression of individual genes; that is, the development of fat in fatty tissue of ruminants is operated and modulated by certain genes [9].

Several studies by foreign and Russian scientists revealed that the $\mathrm{C}$ allele of the CAPN1 gene and the $\mathrm{V}$ allele of the $\mathrm{GH}$ gene are desirable for selection regarding an increase in quantitative and qualitative indicators of beef cattle productivity $[10,11,12,13,14,15,16]$.

Another aspect in assessment of the action of certain genes with regard to farm animal productivity is a complex analysis of quantitative and qualitative indicators of final products. For beef cattle, these indicators are an amount of produced meat, its nutritional properties, energy value, quality and safety, consumer properties, which are also determined by chemical, biochemical and microstructural indicators $[17,18]$.

In this connection, the study of the fatty acid composition of blood plasma, meat productivity of beef cattle of Kazakh white-headed breed of different genotypes by the calpain and growth hormone genes, including biochemical 
and microstructural analysis of muscle tissue is of scientific and practical interest.

The above mentioned was a substantiation of the aim of the present work: to study the biochemical and histological indicators of blood and $m$. longissimus dorsi of young bulls of Kazakh white-headed breed of different genotypes by the CAPN1 and GH genes.

\section{Materials and methods}

The studies were carried out in the laboratory of immunogenetics and DNA technologies, laboratory of veterinary medicine and laboratory of morphology and quality of products of the All-Russian Research Institute of Sheep and Goat Breeding (VNIIOK) - the branch of the Federal State Budgetary Scientific Institution North Caucasian Agrarian Center (North Caucasian FNAC). The object of the research were young bulls of Kazakh white-headed breed $(n=93)$ of SPK Kolhoz Gigant (Blagodarensky district, Stavropol Krai).

DNA was extracted from blood samples using the DIAto $^{\mathrm{mtm}}$ DNAPrep kit (Izogen, Moscow) according to the protocol of the manufacturer. Genotyping by the CAPN1 gene was performed using an analyzer of nucleic acids (ANK-32) by real time PCR with the "CAPN1» kit (Sintol, Russia), by the GH gene using PCR-RFLP with primers (GH-F: 5' - gctgct-cct-gag-cct-tcg - $3^{\prime}$ and GH-R: 5' - gcg-gcg-gca-ctt-catgac-cct-3') and restrictase Alu I (NPO «SibEnzyme»).

The fatty acid (FA) content in blood plasma was determined by the method of gas-liquid chromatography in a form of methyl esters on a gas chromatograph «Cristal 200» with a capillary column HP-FFAP $50 \mathrm{~m}, 0.32 \mathrm{~mm}, 0.5 \mathrm{pm}$ (USA). Fatty acid methyl esters were obtained using the method by Morrison and Smith. FAs were identified using the standards of Sigma and Fluka. Quantitative determination of FAs was carried out with the use of Chromatec Analytic software [19]. The lipid saturation index - a ratio between the sum of saturated fatty acids and the sum of unsaturated fatty acids, was used as an integral indicator that also characterizes the direction of lipid metabolism.

Analysis of the level of total lipids, cholesterol and glucose in blood was carried out according to the methods given in «Methods of veterinary clinical laboratory diagnostics: reference book» [20].

Dynamics of live weight of young bulls of different genotypes was deter-mined by their weighing at birth, on the $240^{\text {th }}$ and $365^{\text {th }}$ days. An average daily gain was calculated by the difference in the values and period of measurement.

During control slaughter of three animals of each genotype at the age of 12 months, samples of m. longissimus dorsi were taken for chemical analysis and histological investigations. An amount of moisture was measured according to GOST 9793-2016 «Meat and meat products. Methods for determination of moisture content» [21]. A meat sample was minced in a homogenizer, thoroughly mixed, dried in a drying oven at a temperature of $103 \pm 2{ }^{\circ} \mathrm{C}$ until constant air-dry mass. The mass fraction of moisture was determined by the difference between the sample weight before and after drying and expressed in percent. An amount of fat was determined according to GOST 23042-2015 «Meat and meat products. Methods of fat determination» [22], by extraction with petroleum ether from a minced and dried sample in the Soxhlet apparatus with the following removal of the solvent and drying of fat until the constant weight. An amount of protein was determined according to GOST 25011-2017 «Meat and meat products. Protein determination methods» [23] using the Kjeldahl method by an amount of nitrogen formed in min-eralization of organic substances in a minced and dried sample and its conversion to protein using the coefficient of 6.25. Caloricity was determined by calculation using V. M. Aleksandrov's equation:

$$
C=[D-(F+A)] \times 4.1+(F \times 9.3),
$$

where $C$ is caloricity, kcal; $D, A, F-$ an amount of dry matter, ash and fat, respectively.

For histological investigations, the samples were fixed in the $10 \%$ solution of neutral formalin and then densified by pouring into gelatin. Sections with a thickness of 7-8 $\mu \mathrm{m}$ were obtained on a freezing microtome. Structural components of muscle tissue were revealed by the methods of staining using Carazzi's hematoxylin with sudan III according to Ehrlich. The muscle bundle area, the quantity of muscle fibers in a bundle, a diameter of a muscle fiber and bundle, a ratio of muscle and connective tissues were determined according to GOST 19496-2013 «Meat and meat products. The method of histological investigation» [24].

The obtained data were subjected to biometrical processing using Microsoft Office and BIOSTAT. Based on the mean values and standard errors, significance of difference between the mean values was calculated using the Student test.

\section{Results and discussion}

As a result of the performed genotyping, it was established that the frequency of the CC, GG, CG genotypes of the CAPN1 gene was $0.06,0.81$ and 0.13 , respectively; the frequency of the VV, LL, LV genotypes of the GH gene was $0.31,0.51$ and 0.18 , respectively. The revealed polymorphism allowed dividing animals according to the established genotypes and studying the biochemical composition of blood plasma in the young bulls with medium indicators of productivity according to a corresponding genotype, as well as performing chemical analysis and histological investigations of $m$. longissimus dorsi.

It was established that the young bulls of Kazakh whiteheaded breed of the homozygous CC and VV genotypes of the CAPN1 and GH genes had $6.3 \%$ and $7.1 \%$ higher sum of unsaturated fatty acids in blood plasma, respectively, compared to the homozygous GG and LL variants. Predominance of unsaturated fatty acids over saturated fatty acids also determined the lower values of the index of lipid metabolism direction in the CC and VV genotypes: 0.92 and 1.00 versus 1.04 and 1.13 in the GG and LL genotypes (Table 1 and Table 2). 
Table 1. Fatty acid composition of blood plasma lipids in young bulls of Kazakh white-headed breed of different genotypes, \%

\begin{tabular}{|c|c|c|c|c|c|c|}
\hline \multirow{2}{*}{ Fatty acids } & \multicolumn{3}{|c|}{ CAPN1 } & \multicolumn{3}{|c|}{ GH } \\
\hline & $\mathrm{CC}$ & CG & GG & VV & LV & LL \\
\hline \multicolumn{7}{|c|}{ Saturated FA } \\
\hline Myristic acid $C_{14: 0}$ & 0.67 & 0.58 & 0.84 & 0.93 & 0.67 & 0.84 \\
\hline Pentadecanoic acid $\mathrm{C}_{15: 0}$ & 0.78 & 0.65 & 0.60 & 0.42 & 0.31 & 0.68 \\
\hline Palmitic acid $\mathrm{C}_{16: 0}$ & 22.12 & 22.81 & 23.02 & 24.21 & 21.67 & 22.99 \\
\hline Heptadecanoic acid $\mathrm{C}_{17: 0}$ & 2.69 & 2.49 & 1.91 & 1.83 & 1.40 & 2.15 \\
\hline Stearic acid $C_{18: 0}$ & 21.81 & 24.11 & 24.51 & 22.51 & 25.82 & 26.33 \\
\hline \multicolumn{7}{|c|}{ Monounsaturated FA } \\
\hline Oleic acid $C_{18: 1}$ & 26.44 & 25.01 & 25.72 & 22.52 & 23.48 & 22.48 \\
\hline Heptadecenoic acid $\mathrm{C}_{17: 1}$ & 1.84 & 1.69 & 1.32 & 2.49 & 1.74 & 1.68 \\
\hline \multicolumn{7}{|c|}{ Polyunsaturated FA } \\
\hline Linoleic acid $\mathrm{C}_{18: 2}$ & 17.35 & 16.97 & 16.01 & 19.25 & 18.23 & 17.01 \\
\hline Linolenic acid $\mathrm{C}_{18: 3}$ & 2.65 & 1.95 & 2.47 & 3.31 & 2.71 & 2.30 \\
\hline Arachidonic acid $\mathrm{C}_{20: 4}$ & 3.63 & 3.48 & 3.30 & 2.25 & 3.90 & 2.98 \\
\hline
\end{tabular}

Table 2. The level of metabolites of energy metabolism in blood plasma in young bulls of Kazakh white-headed breed of different genotypes

\begin{tabular}{|c|c|c|c|c|c|c|c|c|}
\hline \multirow{3}{*}{ gene } & \multirow{3}{*}{ Genotype } & \multicolumn{7}{|c|}{ Indicators } \\
\hline & & \multirow{2}{*}{$\begin{array}{c}\text { lipids, } \\
\mathrm{g} / \mathrm{l}\end{array}$} & \multirow{2}{*}{$\begin{array}{c}\text { cholesterol, } \\
\mathrm{mmol} / \mathrm{l}\end{array}$} & \multirow{2}{*}{$\begin{array}{l}\text { glucose, } \\
\mathrm{mmol} / \mathrm{l}\end{array}$} & \multicolumn{3}{|c|}{ Sum of acids, \% } & \multirow{2}{*}{$\begin{array}{c}\text { lipid } \\
\text { saturation } \\
\text { index }\end{array}$} \\
\hline & & & & & saturated & $\begin{array}{c}\text { mono- } \\
\text { unsaturated }\end{array}$ & $\begin{array}{c}\text { poly- } \\
\text { unsaturated }\end{array}$ & \\
\hline \multirow{3}{*}{ CAPN1 } & $\mathrm{CC}$ & $3.96 \pm 0.21$ & $4.78 \pm 0.33$ & $3.37 \pm 0.31$ & 48.07 & 28.28 & 23.63 & 0.92 \\
\hline & CG & $4.02 \pm 0.23$ & $4.41 \pm 0.22$ & $3.68 \pm 0.22$ & 50.64 & 26.70 & 22.40 & 0.96 \\
\hline & GG & $4.42 \pm 0.17$ & $3.92 \pm 0.17$ & $4.02 \pm 0.19$ & 50.88 & 27.04 & 21.78 & 1.04 \\
\hline \multirow{3}{*}{ GH } & VV & $4.08 \pm 0.28$ & $5.03 \pm 0.24$ & $3.74 \pm 0.37$ & 49.88 & 25.01 & 24.81 & 1.00 \\
\hline & LV & $4.65 \pm 0,33$ & $4.87 \pm 0.18$ & $3.91 \pm 0.18$ & 49.87 & 25.22 & 24.84 & 0.99 \\
\hline & LL & $4.82 \pm 0.17$ & $4.33 \pm 0.31$ & $4.26 \pm 0.22$ & 52.90 & 24.16 & 22.29 & 1.13 \\
\hline
\end{tabular}

Comparative analysis of the content of total lipids, cholesterol and glucose in blood revealed that the total amount of lipids and glucose in blood was lower by on average $11.2 \%$ with on average $12.8 \%$ higher cholesterol level in the CC and VV homozygotes and the CG and LV heterozygotes of the CAPN1 and GH genes compared to the GG and LL homozygotes (Table 2).

Therefore, the obtained data indicate that the intensity of lipid metabolism in youngsters of Kazakh white-headed breed depended on a genotype by the CAPN1 and GH genes. It can be assumed that the carriers of the desirable $\mathrm{C}$ and $\mathrm{V}$ alleles of the CAPN1 and GH genes in the homo- and heterozygote state used the energy components of blood with higher intensity upon realization of the biosynthetic processes.

The revealed regularities were reflected in the value of live weight and average daily gains in different periods of ontogenesis. The carriers of the C allele of CAPN1 and the V allele of GH were superior at birth, weaning and 12 months of age. With that, the largest differences were found between the animals that were homozygous by these alleles and the young bulls, in which genotype they were absent. The difference on the $240^{\text {th }}$ and $365^{\text {th }}$ days was $13.8 \%(\mathrm{P}<0.05)$ and $6.9 \% ; 14.6 \%(\mathrm{P}<0.05)$ and $6.9 \%$, respectively (Table 3$)$.

Comparison of the indicators of chemical analysis of $m$. longissimus dorsi revealed that the CC and VV genotypes were superior to other genotypes in the protein and fat content by $0.28-2.13$ abs. percent.

Different protein and fat content in meat from animals of different genotypes was reflected in its caloricity. For example, the highest level of caloricity was observed in $\mathrm{m}$. longissimus dorsi of the homozygous CC genotype of CAPN1 and the VV genotype of GH (118.9 and $122.5 \mathrm{kcal}$, respectively), which was $8.2 \%$ and $9.3 \%(\mathrm{P}<0.05)$ higher than the similar indicator in meat of the homozygous GG and LL genotypes or on average by $8.7 \%$ (Table 4 ).

Table 3. Dynamics of live weight of young bulls of different genotypes by the CAPN1 and GH genes

\begin{tabular}{|c|c|c|c|c|c|c|}
\hline \multirow[b]{2}{*}{ Gene } & \multirow[b]{2}{*}{ Genotype } & \multirow[b]{2}{*}{ Quantity } & \multicolumn{3}{|c|}{ Live weight, $\mathrm{kg}$} & \multirow{2}{*}{$\begin{array}{c}\text { Average daily gain, } \\
\mathrm{g}\end{array}$} \\
\hline & & & at birth & $\begin{array}{l}\text { at weaning, } \\
240 \text { days }\end{array}$ & 365 days & \\
\hline \multirow{3}{*}{ CAPN1 } & $\mathrm{CC}$ & 6 & $28.1 \pm 0.21$ & $245.5 \pm 4.6$ & $374.2 \pm 5.1$ & $0.948 \pm 0.92$ \\
\hline & CG & 12 & $27.9 \pm 0.18$ & $240.6 \pm 6.5$ & $368.9 \pm 3.6$ & $0.934 \pm 0.72$ \\
\hline & GG & 75 & $27.6 \pm 0.16$ & $215.8 \pm 5.2$ & $349.9 \pm 4.1$ & $0.883 \pm 0.85$ \\
\hline \multirow{3}{*}{ GH } & VV & 29 & $28.3 \pm 0.11$ & $257.9 \pm 7.5$ & $382.7 \pm 4.7$ & $0.969 \pm 0.65$ \\
\hline & LV & 17 & $27.9 \pm 0.18$ & $248.5 \pm 4.5$ & $373.8 \pm 4.2$ & $0.948 \pm 0.92$ \\
\hline & LL & 47 & $27.6 \pm 0.12$ & $225.1 \pm 6.1$ & $357.9 \pm 5.2$ & $0.905 \pm 0.71$ \\
\hline
\end{tabular}


Table 4. Chemical analysis of $m$. longissimus dorsi of young bulls of Kazakh white-headed breed of different genotypes by the CAPN1 and GH genes

\begin{tabular}{|l|c|c|c|c|c|c|}
\hline \multirow{2}{*}{ Indicators } & \multicolumn{5}{|c}{ CAPN1 } & \multicolumn{3}{c}{ GH } \\
& CC & CG & GG & VV & LV & LL \\
\hline \multirow{3}{*}{ Moisture, \% } & 73.47 & 74.90 & 75.02 & 74.37 & 73.61 & 74.84 \\
& \pm 0.27 & \pm 0.29 & \pm 0.18 & \pm 0.21 & \pm 0.17 & \pm 0.24 \\
\hline \multirow{3}{*}{ Dry matter, \% } & 26.53 & 25.10 & 24.98 & 25.63 & 26.39 & 25.16 \\
\hline & \pm 0.16 & \pm 0.12 & \pm 0.15 & \pm 0.17 & \pm 0.09 & \pm 0.17 \\
\hline Protein, \% & 22.45 & 21.49 & 21.12 & 23.12 & 21.99 & 20.99 \\
\hline \multirow{2}{*}{ Fat, \% } & \pm 0.11 & \pm 0.17 & \pm 0.14 & \pm 0.14 & \pm 0.17 & \pm 0.12 \\
\hline \multirow{2}{*}{ Caloricity, kcal } & 2.89 & 2.47 & 2.38 & 2.98 & 2.79 & 2.60 \\
& \pm 0.04 & \pm 0.03 & \pm 0.03 & \pm 0.04 & \pm 0.04 & \pm 0.02 \\
& 1189.1 & 1111.4 & 1099.2 & 1225.3 & 1179.6 & 1121.4 \\
& \pm 7.9 & \pm 2.5 & \pm 2.5 & \pm 5.0 & \pm 3.6 & \pm 9.2 \\
\hline
\end{tabular}

The highest quantity of muscle fibers was observed in the young bulls with the desirable CC and VV genotypes; the quantity was larger compared to the animals of the same age with the GG and LL genotypes in the CAPN1 and GH genes, respectively, by 36.82 fibers $/ \mathrm{mm}^{2}$ or $19.7 \%(\mathrm{P}<0.01)$ and 55.7 fibers $/ \mathrm{mm}^{2}$ or $31.4 \%$, on average $25.5 \%(\mathrm{P}<0.01)$ and was significant (Table 5 and Figure 1).
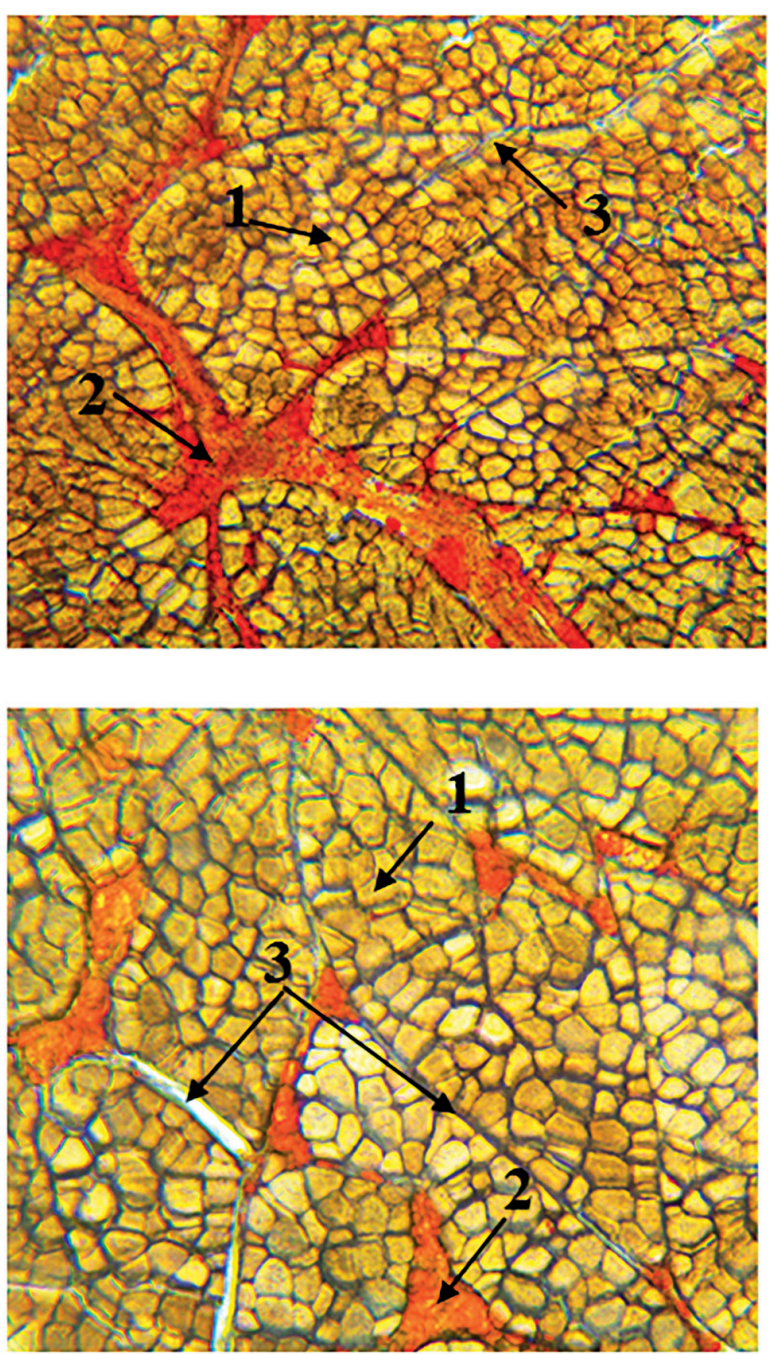

Table 5. Microstructural analysis of $m$. longissimus dorsi of young bulls of Kazakh white-headed breed of different genotypes by the CAPN1 and GH genes

\begin{tabular}{|c|c|c|c|c|c|c|}
\hline \multirow[b]{2}{*}{ Gene } & \multirow[b]{2}{*}{ 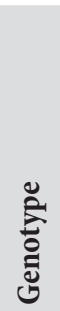 } & \multicolumn{5}{|c|}{ Indicators } \\
\hline & & 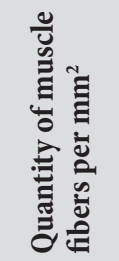 & 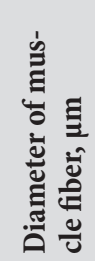 & 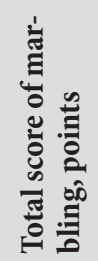 & 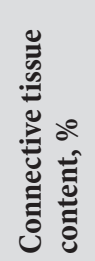 & 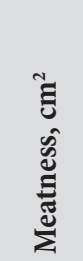 \\
\hline \multirow{3}{*}{ CAPN1 } & $\mathrm{CC}$ & $\begin{array}{c}224.07^{\star} \\
\pm 8.31\end{array}$ & $\begin{array}{c}33.57^{\star} \\
\pm 0.43\end{array}$ & $\begin{array}{l}31.27 \\
\pm 0.82\end{array}$ & $\begin{array}{l}10.60 \\
\pm 0.31\end{array}$ & $\begin{array}{r}47.93 \\
\pm 3.65\end{array}$ \\
\hline & CG & $\begin{array}{r}219.85 \\
\pm 1.96\end{array}$ & $\begin{array}{l}36.25 \\
\pm 0.59\end{array}$ & $\begin{array}{l}28.77 \\
\pm 0.76\end{array}$ & $\begin{array}{l}11.53 \\
\pm 0.44\end{array}$ & $\begin{array}{r}36.04 \\
\pm 1.79\end{array}$ \\
\hline & GG & $\begin{array}{c}187.25 \\
\pm 3.60\end{array}$ & $\begin{array}{l}37.80 \\
\pm 1.93\end{array}$ & $\begin{array}{l}27.75 \\
\pm 0.14\end{array}$ & $\begin{array}{l}12.73 \\
\pm 0.37\end{array}$ & $\begin{array}{r}28.64 \\
\pm 3.03\end{array}$ \\
\hline \multirow{3}{*}{ GH } & VV & $\begin{array}{c}233.18^{\star} \\
\pm 5.72\end{array}$ & $\begin{array}{l}33.78^{\star} \\
\pm 0.17\end{array}$ & $\begin{array}{l}29.28 \\
\pm 0.41\end{array}$ & $\begin{array}{l}10.93 \\
\pm 0.35\end{array}$ & $\begin{array}{l}52.77 \\
\pm 0.61\end{array}$ \\
\hline & LV & $\begin{array}{l}199.25 \\
\pm 5.41\end{array}$ & $\begin{array}{l}35.89 \\
\pm 0.47\end{array}$ & $\begin{array}{l}27.94 \\
\pm 0.99\end{array}$ & $\begin{array}{l}12.73 \\
\pm 0.59\end{array}$ & $\begin{array}{r}40.92 \\
\pm 0.67\end{array}$ \\
\hline & LL & $\begin{array}{c}177.48 \\
\pm 1.89\end{array}$ & $\begin{array}{l}40.60 \\
\pm 1.41\end{array}$ & $\begin{array}{l}25.43 \\
\pm 0.60\end{array}$ & $\begin{array}{l}14.27 \\
\pm 0.87\end{array}$ & $\begin{array}{l}31.92 \\
\pm 1.51\end{array}$ \\
\hline
\end{tabular}

\section{${ }^{\star} \mathbf{P}<0,01$}

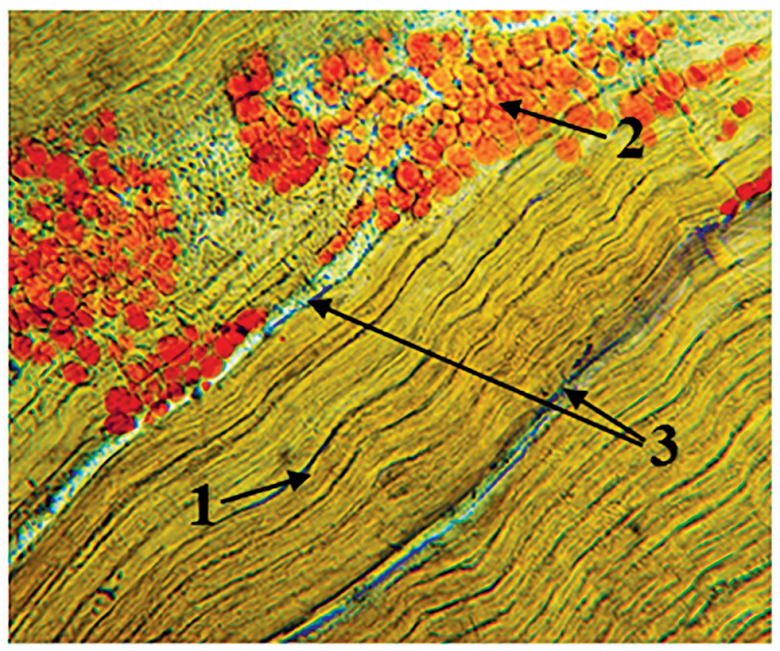

a)

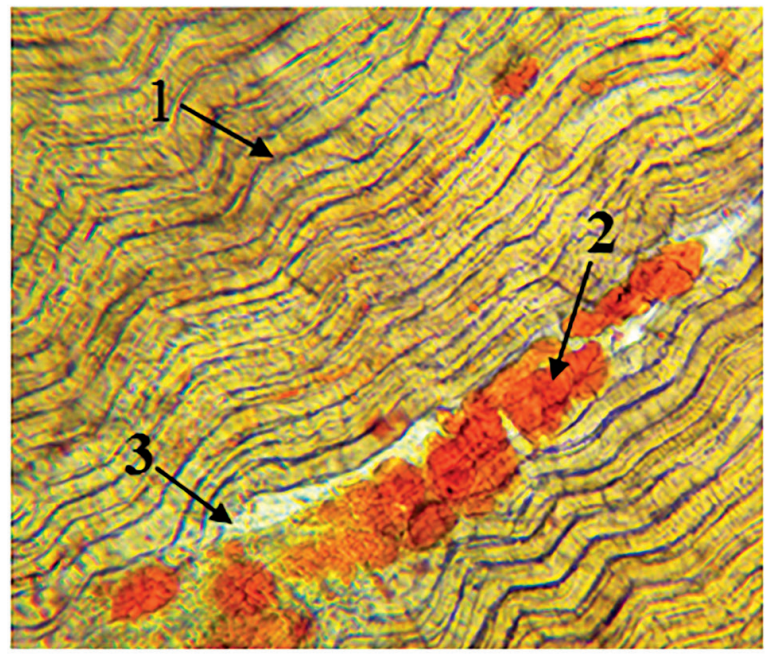

b)

Figure 1. Histological sections of $m$. longissimus dorsi of young bulls of Kazakh white-headed breed of different genotypes by the CAPN1 gene a) CC genotype b) GG genotype (left — cross sections; right — longitudinal sections)

1 - muscle fibers; 2 - fatty tissue; 3 - connective tissue (staining: Carazzi’s hematoxylin with sudan III, $10 \times 40$ magnification) 
The muscle fiber diameter was lower by $4.23 \mu \mathrm{m}$ or $11.9 \%$ and by $6.82 \mu \mathrm{m}$ or $16.8 \%$, respectively, in the animals with the desirable genotype at high significance $(\mathrm{P}<0.001)$. Desirable genotypes also had an advantage in terms of the value of the marbling coefficient: the difference was $12.6 \%$ in the CAPN1 gene, $15.1 \%$ in the GH gene. At the same time, the content of connective tissue was higher by 2.13 and 3.34 abs. percent in the carriers of the undesirable $G$ and $\mathrm{L}$ alleles in the homozygous state.

\section{Conclusion}

As a result of DNA typing, the frequency of desirable genotypes by the CAPN1 and GH genes among youngsters of Kazakh white-headed breed was established.

The carriers of the desirable CC and VV genotypes in the CAPN1 and GH genes had the largest live weight at the age of 8 and 12 months. Their superiority over the GG and LL genotypes was $13.8 \%$ and $6.9 \%, 14.6 \%$ and $6.9 \%$, respectively.

The intensity of lipid metabolism in the young bulls of Kazakh white-headed breed depended on a genotype in the CAPN1 and GH genes. The carriers of the desirable alleles ( $\mathrm{C}$ and $\mathrm{V}$ ) in the homo- and heterozygote state in the CAPN1 and GH genes used the energy components of blood with higher intensity upon realization of the biosynthetic processes, which is indicated by their superiority in terms of the sum of saturated and unsaturated fatty acids and the index of lipid metabolism direction.

Muscle tissue of the animals of the CC and VV genotypes was characterized by the highest content of protein, fat and, respectively, energy value compared to the GG and LL genotypes. Meat from the young bulls of the desired genotypes had higher scores for marbling due to a larger quantity of interfiber fat inclusions.

Therefore, genotyping of youngsters of Kazakh whiteheaded breed by the CAPN1 and GH genes, selection of animals with desirable genotypes and their replication through the targeted selection of parent pairs will allow not only increasing meat productivity of a herd, but also will facilitate production of high quality beef.

\section{REFERENCES}

1. Soloshenko, V.A., Goncharenko, G.M., Dvoryatkin, A.A., Pleshakov, V.A. (2013). Possibilities of using genetic markers in selection of beef cattle to improve the quality of meat indicators. The herald of beef cattle breeding, 1(79), 37-41. (In Russian)

2. Chizhova, L.N., Sharko, G.N., Mihajlenko, A.K. (2016). Genetik markers in the meat animal husbandry. Proceedings of the All-Russian Research Institute of Sheep and Goat Breeding, 9(2), 258-264. (In Russian)

3. Dzhulamanov, K.M., Dubovskova, M. P., Vorozheikin, A. M., Gerasimov, N. P., Kolpakov, V. I. (2016). Slaughter indicators of steers taking into account the selection of parents by genes markers of meat productivity. The herald of beef cattle breeding, 2(94), 26-32. (In Russian)

4. Selionova, M.I., Chizhova, L. N., Dubovskova, M. P., Surzhikova, E. S., Kononova, L. V., Sharko, G. N. (2017). Polymorphism peculiarities of growth hormone (GH), calpain (CAPN1) genes of beef sires. The herald of beef cattle breeding, 2(98), 65-72. (In Russian)

5. Allais, S., Journaux, L., Levéziel, H., Payet-Duprat, N., Raynaud, P., Hocquette, J.F., Lepetit, J., Rousset, S., Denoyelle, C., Bernard-Capel, C., Renand, G. (2011). Effects of polymorphisms in the calpastatin and mu-calpain genes on meat tenderness in 3 French beef breeds. Journal of Animal Science, 89(1), 1-11. https://doi.org/10.2527/jas.2010-3063

6. Tjulkin, S.V., Ahmetov, T.M., Valiullina, E.F., Vafin R. R. (2012). Polymorphism of genes for somatotropin, prolactin, leptin, and thyroglobulin in stud bulls. Vavilov Journal of Genetics and Breeding, 16(4-2), 1008-1012. (In Russian)

7. Gorlov, I.F., Fedunin, A.A., Randelin, D.A., Sulimova, G.E. (2014). Polymorphism of bGH, RORC and DGAT1 genes in Russian beef cattle breeds. Russian Journal of Genetics, 50(12), 13021307. https://doi.org/10.1134/s1022795414120035

8. Surundaeva, L.G. (2016). Comparative analysis of the genetic structure of populations of beef cattle according to polymorphic hormone variants of somatotropin and thyroglobulin. The herald of beef cattle breeding, 4(95), 21-29. (In Russian)

9. Frolov, A.N., Zavialov, O.A., Kharlamov, A.V., Miroshnikov, A.M. (2015). The effect of the genotype steers on the quality of fat and its fatty acid composition. Achievements of Science and Technology of AIC, 29(2), 43-45. (In Russian)

10. Makaev, Sh.A., Taiguzin, R. Sh., Lyapin, O. A, Fomin, A. V. (2019). Genetic characteristic of the kazakh white-headed cattle. News of the Orenburg State Agrarian University, 6(80), 281-285. (in Russian)

11. Hartatik, T., Fathoni, A., Bintara, S., Panjono, I., Eidyobroto, B.P., Agus, A., igs. Budisatria, I., Leroy, P. (2020). Short communication: The genotype of growth hormone gene that affects the birth weight and average daily gain in crossbred beef cattle. Biodiversitas Journal of Biological Diversity, 21(3), 941-945. https://doi.org/10.13057/biodiv/d210312

12. Costello, S., O'Doherty, E., Troy, D.J., Ernst, C.W., Kim, K. S., Stapleton, P., Sweeney, T., A. M. Mullen, A.M. (2007). Association of polymorphisms in the calpain I, calpain II and growth hormone genes with tenderness in bovine $M$. Iongissimus dorsi. Meat Science, 75(4), 551-557. https://doi.org/10.1016/j.meatsci.2006.06.021

13. Curi, R.A., Chardulo, L.A.L., Giusti, J., Silveira, A.C., Martins, C.L., Oliveira, H.N. (2010). Assessment of GH1, CAPN1 and CAST polymorphisms as markers of carcass and meat traits in Bos indicus and Bos taurus-Bos indicus cross beef cattle. Meat Science, 86(4), 915-920. https://doi.org/10.1016/j.meatsci.2010.07.016

14. Tait, R.G., Shackelford, S.D., Wheeler, T. L., King, D.A., Casas, E., Thallman, R.M., Smith, T. P. L., Bennett, G. L. (2014). $\mu$-Calpain, calpastatin, and growth hormone receptor genetic effects on preweaning performance, carcass quality traits, and residual variance of tenderness in Angus cattle selected to increase minor haplotype and allele frequencies1,2,3. Journal of Animal Science, 92(2), 456-466. https://doi.org/10.2527/jas.2013-7075

15. Cafe, L. M., McIntyre, B. L., Robinson, D. L., Geesink, G. H., Barendse, W., Pethick, D. W., Thompson, J. M., Greenwood, P. L. (2010). Production and processing studies on calpain-system gene markers for tenderness in Brahman cattle: 2. Objective meat quality1. Journal of Animal Science, 88(9), 3059-3069. https://doi.org/10.2527/jas.2009-2679

16. Tatsuda, K., Oka, A., Iwamoto, E., Kuroda, Y., Takeshita, H., Kataoka, H., Kouno, S. (2008). Relationship of the bovine growth hormone gene to carcass traits in Japanese black cattle. Journal of animal breeding and genetics, 125(1), 45-49. https://doi. org/10.1111/j.1439-0388.2007.00688.x

17. Khvylya, S.I., Pchelkina, V.A., Burlakova, S.S. (2011). Standardized histological methods for assessing the quality of meat and meat products. Vsyo o myase, 6, 32-35. (In Russian)

18. Budaeva, A.B., Kozub, Yu. A., Ryadinskaya, N. I., Tabakova, M. A. (2019). Histological structure of the longest back muscle of bulls of black-and-white and kazakh white-headed breeds. Bulletin of the Irkutsk State Agricultural Academy, 90, 139-149. (In Russian)

19. Lyudinina, A. Yu., Kochan, T.I., Boiko, Ye. R. (2006). Gas liquid chromatographic determination of tricarbonic cycle acids in human plasma. Russian Clinical Laboratory Diagnostics, 11, 13-14. (In Russian)

20. Kondrakhin, I.P., Arkhipov, A.V., Lechenko, V.I., Talanov, G.A., Frolova, L.A., Novikov, V.E. (2004). Methods of veterinary clinical 
laboratory diagnostics. Moscow: Kolos. - 520 p. ISBN5-95320165-6 (In Russian)

21. GOST 9793-2016 "Meat and meat products. Methods of moisture determination". Moscow: Standardinform, 2018. -6 p. 22. GOST 23042-2015 "Meat and meat products. Methods for determining fat". Moscow: Standardinform. 2016. - 9 p.
23. GOST 25011-2017 "Meat and meat products. Methods of protein determination". Moscow: Standardinform, 2018. $14 \mathrm{p}$.

24. GOST 19496-2013 "Meat and meat products. Method of histological research". Moscow: Standardinform, 2014. $10 \mathrm{p}$.

\section{AUTHOR INFORMATION}

Marina I. Selionova - doctor of biological sciences, professor, head of the Department of breeding, genetics and animal biotechnology, Russian State Agrarian University - Moscow Timiryazev Agricultural Academy. 127550, Moscow, Timiryazevskaya str., 49. Tel.:+7-968-266-33-03. E-mail: selionova@rgau-msha.ru

ORCID: https://orcid.org/0000-0002-9501-8080

* corresponding author

Viktoria R. Plakhtyukova - graduate student, Russian State Agrarian University - Moscow Timiryazev Agricultural Academy. 127550, Moscow, Timiryazevskaya str., 49. Tel.: +7-988-761-32-93. E-mail: viktoriyaplahtyukova@mail.ru

ORCID: https://orcid.org/0000-0002-0016-5003

All authors bear responsibility for the work and presented data.

All authors made an equal contribution to the work.

The authors were equally involved in writing the manuscript and bear the equal responsibility for plagiarism.

The authors declare no conflict of interest.

Received 21.04.2020 Accepted in revised 12.05.2020 Accepted for publication 20.05.2020 